A) Check for updates

Cite this: Food Funct., 2017, 8, 2013

\section{Non-edible parts of Solanum stramoniifolium Jacq. - a new potent source of bioactive extracts rich in phenolic compounds for functional foods}

\author{
Blanka Svobodova, a,b Lillian Barros, (D) *a,c Tomas Sopik, (iD b Ricardo C. Calhelha, ${ }^{a}$ \\ Sandrina Heleno, (D) a Maria Jose Alves, ${ }^{d}$ Simone Walcott, ${ }^{e}$ Vlastimil Kuban ${ }^{\mathrm{b}}$ and \\ Isabel C. F. R. Ferreira*a
}

Received 21st February 2017, Accepted 17th April 2017

DOI: $10.1039 /$ c7fo00297a

rsc.li/food-function

\begin{abstract}
Extracts prepared from leaves, roots, and stems of Solanum stramoniifolium Jacq. (Solanaceae) in $80 \%$ ethanol have been tested for their in vitro antioxidant, anti-inflammatory, antimicrobial, and cytotoxic activities with an aim to find new sources of substances for functional foods and food additives. The root extract revealed the highest antioxidant activity in all assays exceeding the trolox capacity, and was the only extract that inhibited nitric oxide production in mouse macrophage cells, showing also the capacity to suppress the growth of all tested human tumor cell lines (MCF-7, NCl-H460, HeLa and HepG2). The leaf extract showed the strongest antimicrobial activity inhibiting all tested clinical isolates. To the author's best knowledge it was the first time that all individual parts of this plant were tested for biological activity together with the phenolic compound characterization.
\end{abstract}

\section{Introduction}

In recent years, food industry is interested in the application of naturally occurring phytochemical compounds with biological activity to food products to enhance their nutraceutical value, health benefits, safety and shelf-life. ${ }^{1}$ Moreover, customer demand for more natural and safer food additives and the growing number of chronic diseases motivate scientists to search for new substances that would meet such expectations. ${ }^{2}$

Plants from tropical regions, such as Trinidad and Tobago, grow in a highly competitive environment and therefore produce large amounts of secondary metabolites for their defense. These edible and medicinal plants, usually rich in polyphenols, are often a good source of new bioactive compounds. ${ }^{3}$ Solanum stramoniifolium Jacq. (coco-chat) is a hairy fruited pea-eggplant of the Solanaceae family with distribution

\footnotetext{
${ }^{a}$ Mountain Research Centre (CIMO), ESA, Polytechnic Institute of Bragança, Campus de Santa Apolonia, 1172, 5300-253 Bragança, Portugal. E-mail: iferreira@ipb.pt, lillian@ipb.pt; Fax:+351-273-325405, +351-273-325405; Tel: +351-273-303219, +351-273-303903

${ }^{b}$ Department of Food Technology, Faculty of Technology, Tomas Bata University in Zlin, Vavreckova 275, 76272 Zlin, Czech Republic

${ }^{c}$ Laboratory of Separation and Reaction Engineering (LSRE) - Associate Laboratory LSRE/LCM, Faculty of Engineering, University of Porto, Porto, Portugal

${ }^{d}$ Escola Superior de Saúde, Instituto Politécnico de Bragança, Av. D. Afonso V, 5300-121 Bragança, Portugal

${ }^{e}$ Faculty of Science and Technology, University of West Indies, St Augustine Campus, Trinidad and Tobago
}

in Asia, South America, Mesoamerica, and the Caribbean region. It is a perennial shrub, 1 to 2 meters high and about as broad; its stems, branches as well as leaves are sparsely prickly. Fruits are 1-2 cm in diameter, globose, hairy, orange or red when ripe. ${ }^{4}$ The ripe fruits are consumed while leaves and roots are used in traditional medicine to treat thrush, cold, venereal diseases, inflammation, asthma, arthritis, liver problems, malaria and cancer. ${ }^{5-8}$

In $S$. stramoniifolium plants originating from Thailand, fruits have been excessively tested, however other plant parts remain unexplored. The antioxidant activity (DPPH and ABTS tests, respectively) of water and methanol extracts was described as weak and explained by the low total phenolic content in the fruits. ${ }^{9,10}$ Methanol and ethyl acetate extracts of fruits inhibited Gram-negative bacteria Escherichia coli in the disc diffusion test, however the same extracts showed no activity against Salmonella typhimurium, Shigella sonnei, Helicobacter pylori, Streptococcus pyogenase, Salmonella typhi, Staphylococcus aureus, Streptococcus viridians, and Enterococci sp. ${ }^{11}$ On the contrary, the water extract of seeds contained small proteins ( $\mathrm{MW}<14.4 \mathrm{kDa}$ ) with significant antimicrobial activity against both Gram-positive and Gram-negative bacteria with Bacillus subtilis, Bacillus licheniformis and Pseudomonas aeruginosa being the most sensitive in the disc diffusion test, and with no inhibition of $E$. coli and Klebsiella pneumoniae. ${ }^{12}$ The bioactive compounds of this species are, nevertheless, unexplored. The ethanolic extract of roots revealed the presence of alkaloids, flavonoids, tannins, triterpenes and 
saponins in a Brazilian study. ${ }^{13}$ The only study on phytochemical compounds of $S$. stramoniifolium from Trinidad and Tobago described the isolation of solamargine, a solasodine glycoalkaloid. ${ }^{14}$

According to the World Health Organization, chronic disorders such as cancer, diabetes and hypertension are becoming the major causes of mortality not only in Trinidad and Tobago, but also worldwide. ${ }^{15}$ Therefore, it would be desirable to search for new tropical plant sources rich in bioactive compounds that can be applied either as nutraceuticals or in functional foods to fight and prevent these diseases. The combination of the health benefits, lately required by consumers, and the positive role in food safety and storage due to the strong antimicrobial and antioxidant activity of this plant may be of great interest to the modern food industry in development of new products.

To the author's best knowledge, this is the first detailed study of individual parts, such as leaves, stems and roots of S. stramoniifolium reporting their anti-inflammatory, antimicrobial, antioxidant, and cytotoxic activities associated with the phenolic compound profiles.

\section{Materials and methods}

\subsection{Reagents and standards}

Acetonitrile $99.9 \%$ of HPLC grade was from Fisher Scientific (Lisbon, Portugal). The standards trolox (6-hydroxy-2,5,7,8tetramethylchroman-2-carboxylic acid), $\beta$-carotene and ellipticine were purchased from Sigma-Aldrich (St Louis, MO, USA), as also acetic acid, phosphate buffered saline (PBS), sulforhodamine B (SRB), and lipopolysaccharide (LPS). Phenolic compound standards were from Extrasynthèse (Genay, France). DPPH (2,2-diphenyl-1-picrylhydrazyl) was obtained from Alfa Aesar (Ward Hill, MA, USA). The Griess reagent system was purchased from Promega Corporation (Madison, WI, USA). The culture media Muller Hinton broth (MHB) and Tryptic Soy Broth (TSB) were obtained from Biomerieux (Marcy l'Etoile, France). The dye $p$-iodonitrotetrazolium chloride (INT) was purchased from Sigma-Aldrich (Spruce Street; St Louis, MO) and was used as a microbial growth indicator. All other chemi- cals were of analytical purity and obtained from common suppliers. Water was treated via the purification system Milli-Q water (TGI Pure Water Systems, Greenville, SC, USA).

\subsection{Plant material}

Plant material was harvested during May 2015 in Santa Cruz area (Trinidad), after consultation with local healers. Table 1 presents the botanical name, local names, plant parts investigated and popular uses of the plant in natural medicine. The samples were authenticated by Dr Walcott at the National Herbarium, University of West Indies, St Augustine Campus, Trinidad and voucher specimen TRIN 40646 was deposited thereby.

\subsection{Preparation of plant extracts}

Leaves, stems and roots were air dried separately right after harvesting and ground to a fine powder by using an electric laboratory scale mill (Grindomix, Retsch, Germany). Each sample $(1.5 \mathrm{~g})$ was extracted twice with $30 \mathrm{~mL}$ of ethanol/water $(80: 20, \mathrm{v} / \mathrm{v})$ for 1 hour at $150 \mathrm{rpm}$ and room temperature. Subsequently, the supernatant was filtered through Whatman No. 4 filter paper. Ethanol was then evaporated under vacuum at $40{ }^{\circ} \mathrm{C}$ (Büchi R-210; Flawil, Switzerland) and the water residue was lyophilized (Freezone 4.5 model 7750031, Labconco, Kansas City, MO, USA). The resulting fine powder (20 mesh) was mixed to yield homogenized crude extracts and stored in the dark at room temperature until tested. The methodology routinely used in our laboratory was modified according to ethnopharmaceutical requirements on solvents. ${ }^{16}$

\subsection{Phenolic compounds' profile}

A routine method used in our laboratory was followed. ${ }^{17}$ Dry lyophilized extracts were re-dissolved in water/ethanol $(80: 20$, $\mathrm{v} / \mathrm{v}$ ) using a sonic bath, filtered through a $0.22 \mu \mathrm{m}$ nylon filter and subjected to HPLC analysis.

Chromatographic data were acquired using a Dionex Ultimate 3000 UPLC (Thermo Scientific, San Jose, CA, USA). This system consists of a diode array detector coupled to an electrospray ionization mass detector (LC-DAD-ESI/MS ${ }^{n}$ ), a quaternary pump, an auto-sampler (kept at $5{ }^{\circ} \mathrm{C}$ ), a degasser

Table 1 Ethnomedicinal information on Solanum stramoniifolium Jacq

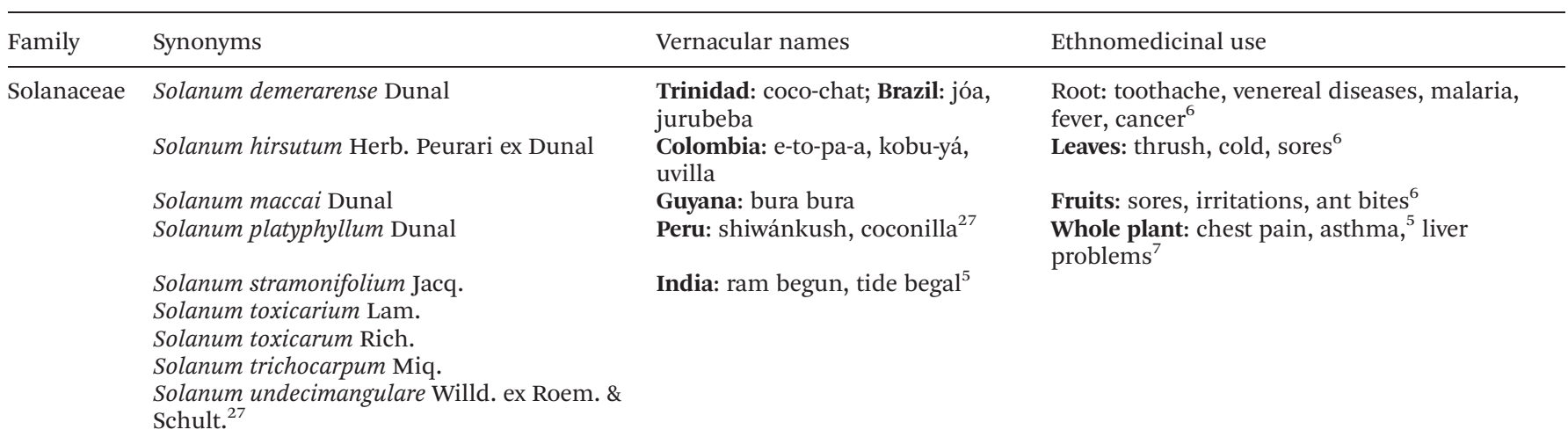


and an automated thermostated column section (kept at $\left.35{ }^{\circ} \mathrm{C}\right)$. The Waters Spherisorb S3 ODS-2 $\mathrm{C}_{18}(3 \mu \mathrm{m}, 4.6 \times$ $150 \mathrm{~mm}$, Waters, Milford, MA, USA) column was used for chromatographic separations. The solvents used were (A) $0.1 \%$ formic acid in water and (B) acetonitrile. The gradient elution applied was: $15 \%$ B (0-5 min), $15 \%$ B to $20 \%$ B (5-10 $\mathrm{min})$, 20-25\% B (10-20 $\mathrm{min}), 25-35 \%$ B (20-30 $\mathrm{min}), 35-50 \%$ B (30-40 $\mathrm{min}$ ), the column was then re-equilibrated, using a flow

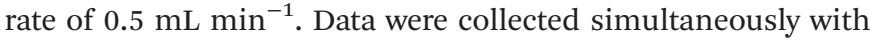
a DAD (280 and $370 \mathrm{~nm}$ ) and in a mass spectrometer. Negative mode was chosen for MS detection on a Linear Ion Trap LTQ XL mass spectrometer (ThermoFinnigan, San Jose, CA, USA). Sheath gas (nitrogen) was kept at 50 psi. Other parameter settings: source temperature: $325^{\circ} \mathrm{C}$, spray voltage: $5 \mathrm{kV}$, capillary voltage: $-20 \mathrm{~V}$, tube lens offset: $-66 \mathrm{~V}$, collision energy: 35 arbitrary units. The full scan captured the mass between $\mathrm{m} / \mathrm{z}$ 100 and 1500. The Xcalibur ${ }^{\circledR}$ data system (ThermoFinnigan, San Jose, CA, USA) was used for data acquisition.

For identification of the phenolic compounds, retention times, UV-VIS and mass spectra were compared with available standards. Data from the literature were used to tentatively identify the remaining compounds. Calibration curves of available phenolic standards were constructed based on the UV signal to perform quantitative analysis. Identified phenolic compounds with unavailable commercial standard were quantified via calibration curves of the most similar standard available. The results were expressed as $\mathrm{mg} \mathrm{g}^{-1}$ of dry extract.

\subsection{Biological activity screening}

Antibacterial activity. Clinical isolates from patients hospitalized in the Local Health Unit of Bragança and Hospital Centre of Trás-os-Montes and Alto-Douro-Vila Real, Northeast of Portugal were used in the assay. Four Gram-positive bacteria
(Enterococcus faecalis isolated from urine; Listeria monocytogenes isolated from cerebrospinal fluid; MSSA: methicillin-sensitive Staphylococcus aureus isolated from wound exudate and MRSA: methicillin-resistant Staphylococcus aureus, isolated from expectoration), and six Gram-negative bacteria (Acinetobacter baumannii and Pseudomonas aeruginosa isolated from expectoration; Escherichia coli, Escherichia coli spectrum extended producer of $\beta$-lactamases (ESBL); Klebsiella pneumoniae, Klebsiella pneumoniae ESBL, all isolated from urine) were used to screen the antibacterial activity of the extracts. Microorganism identification and susceptibility tests were performed on the MicroScan panels (MicroScan®; Siemens Medical Solutions Diagnostics, West Sacramento, CA, USA) using the microdilution method. The interpretation criteria were based on Interpretive Breakpoints as indicated in the Clinical and Laboratory Standards Institute $^{18}$ and in the European Committee on Antimicrobial Susceptibility Testing. ${ }^{19}$

A microdilution method with rapid $p$-iodonitrotetrazolium chloride (INT) colorimetric assay according to Kuete et al. ${ }^{20}$ with some modifications was performed. The extract was diluted in appropriate media according to bacterial requirements and successive dilutions were carried out in the wells (20 to $0.156 \mathrm{mg} \mathrm{mL}^{-1}$ of final concentration). Three negative controls (MHB/TSB, the extract, and medium with antibiotic) and a positive control (MHB and each inoculum) were prepared. For the Gram-negative bacteria, negative control antibiotics, such as amikacin ( $K$. pneumoniae ESBL and $P$. aeruginosa), tobramycin (A. baumannii), amoxicillin/ clavulanic acid (E. coli and $K$. pneumoniae) and gentamicin (E. coli ESBL) were used. The concentration used was based on the MIC obtained (Table 2). For the Gram-positive bacteria, ampicillin (L. monocytogenes) and vancomycin (MSSA, MRSA and E. faecalis) were used (Table 3).

Table 2 Resistance profile of Gram-negative bacteria to different antibiotics; MIC values $\left(\mu \mathrm{g} \mathrm{ml}^{-1}\right.$ )

\begin{tabular}{|c|c|c|c|c|c|c|c|c|c|c|c|c|}
\hline \multirow{2}{*}{$\begin{array}{l}\text { Antibiotics } \\
\text { Ampicillin }\end{array}$} & \multicolumn{2}{|c|}{$\begin{array}{l}\text { A. } \\
\text { baumannii }\end{array}$} & \multicolumn{2}{|l|}{ E. coli } & \multicolumn{2}{|c|}{ E. coli $\mathrm{ESBL}$} & \multicolumn{2}{|c|}{$\begin{array}{l}\text { K. } \\
\text { pneumoniae }\end{array}$} & \multicolumn{2}{|c|}{$\begin{array}{l}K . \\
\text { pneumoniae } \\
\text { ESBL }\end{array}$} & \multicolumn{2}{|c|}{$\begin{array}{l}P . \\
\text { aeruginosa }\end{array}$} \\
\hline & na & & $>8$ & $\mathrm{R}$ & na & & $>8$ & $\mathrm{R}$ & $\geq 32$ & $\mathrm{R}$ & na & \\
\hline Amoxicillin/clavulanic acid & na & & $\leq 8 / 4$ & $\mathrm{~S}$ & na & & $\leq 8 / 4$ & $\mathrm{~S}$ & $\geq 32$ & $\mathrm{R}$ & na & \\
\hline Amikacin & na & & & na & 16 & I & na & & $\leq 2$ & $\mathrm{~S}$ & $\leq 8$ & $\mathrm{~S}$ \\
\hline Cefuroxime & na & & $\leq 4$ & $\mathrm{~S}$ & na & & $>8$ & $\mathrm{R}$ & $\geq 64$ & $\mathrm{R}$ & na & \\
\hline Cefotaxime & $>32$ & $\mathrm{R}$ & $\leq 1$ & $\mathrm{~S}$ & na & & $>2$ & $\mathrm{R}$ & $\geq 64$ & $\mathrm{R}$ & na & \\
\hline Ceftazidime & 16 & I & $\leq 1$ & $\mathrm{~S}$ & $\geq 64$ & $\mathrm{R}$ & na & & 16 & $\mathrm{R}$ & $>8$ & $\mathrm{R}$ \\
\hline Norfloxacin & na & & $>8$ & $\mathrm{R}$ & na & & $>1$ & $\mathrm{R}$ & na & & na & \\
\hline Levofloxacin & na & & & na & na & & na & & $\geq 8$ & $\mathrm{R}$ & $>2$ & $\mathrm{R}$ \\
\hline Ciprofloxacin & $>2$ & $\mathrm{R}$ & $>1$ & $\mathrm{R}$ & 0.5 & $\mathrm{~S}$ & $>1$ & $\mathrm{R}$ & $\geq 4$ & $\mathrm{R}$ & $>1$ & $\mathrm{R}$ \\
\hline Nitrofurantoin & na & & $\leq 32$ & $\mathrm{~S}$ & na & & $>64$ & $\mathrm{R}$ & 256 & $\mathrm{R}$ & na & \\
\hline Fosfomycin & na & & $\leq 16$ & $\mathrm{~S}$ & na & & $\leq 32$ & $\mathrm{~S}$ & na & & na & \\
\hline Colistin & na & & & na & $\leq 0.5$ & $\mathrm{~S}$ & na & & na & & $\leq 4$ & $\mathrm{~S}$ \\
\hline Gentamicin & 4 & $\mathrm{R}$ & $>4$ & $\mathrm{R}$ & $\leq 1$ & $\mathrm{~S}$ & $\leq 2$ & $\mathrm{~S}$ & $\geq 16$ & $\mathrm{R}$ & $>4$ & $\mathrm{R}$ \\
\hline Imipenem & na & & & na & 0.5 & $\mathrm{~S}$ & na & & na & & $>8$ & $\mathrm{R}$ \\
\hline Meropenem & na & & & na & $\leq 0.25$ & $\mathrm{~S}$ & na & & $\leq 0.25$ & & $>8$ & $\mathrm{R}$ \\
\hline Piperacillin/tazobactam & na & & & na & $\leq 4$ & I & $\leq 8$ & S & $\geq 128$ & $\mathrm{R}$ & $>16$ & $\mathrm{R}$ \\
\hline Trimethoprim/sulfamethoxazole & na & & $>4 / 76$ & $\mathrm{R}$ & $\leq 20$ & $\mathrm{~S}$ & $>4 / 76$ & $\mathrm{R}$ & $\geq 320$ & $\mathrm{R}$ & na & \\
\hline Tobramycin & $\leq 2$ & $\mathrm{~S}$ & & na & $\geq 16$ & $\mathrm{R}$ & na & & $\geq 16$ & $\mathrm{R}$ & $>4$ & $\mathrm{R}$ \\
\hline
\end{tabular}

S - susceptible; I - intermediate; R - resistant; classification according to the interpretative breakpoints suggested by Clinical and Laboratory Standards Institute (CLSI) and European Committee on Antimicrobial Susceptibility Testing (EUCAST); na - not applicable. 
Table 3 Resistance profile of Gram-positive bacteria to different antibiotics; MIC values $\left(\mu \mathrm{g} \mathrm{ml}^{-1}\right)$

\begin{tabular}{|c|c|c|c|c|c|c|c|}
\hline Antibiotics & MRSA & & MSSA & & E. faecalis & & L. monocytogenes \\
\hline Penicillin & $>8$ & $\mathrm{R}$ & $\leq 0.12$ & $\mathrm{~S}$ & na & & na \\
\hline Ampicillin & na & & na & & $\leq 4$ & $\mathrm{~S}$ & $\leq 0.2$ \\
\hline Oxacillin & $>0.25$ & $\mathrm{R}$ & $\leq 0.25$ & $\mathrm{~S}$ & na & & na \\
\hline Clindamycin & na & & $>0.5$ & $\mathrm{R}$ & na & & na \\
\hline Erythromycin & na & & $>2$ & $\mathrm{R}$ & na & & na \\
\hline Ceftaroline & $\leq 1$ & $\mathrm{~S}$ & na & & na & & na \\
\hline Gentamicin & na & & $\leq 1$ & $\mathrm{~S}$ & na & & na \\
\hline Ciprofloxacin & na & & $>1$ & $\mathrm{R}$ & na & & na \\
\hline Levofloxacin & na & & $>2$ & $\mathrm{R}$ & na & & na \\
\hline Nitrofurantoin & na & & na & & $\leq 64$ & $\mathrm{~S}$ & na \\
\hline Linezolid & $\leq 4$ & $\mathrm{~S}$ & na & & na & & na \\
\hline Trimethoprim/sulfamethoxazole & na & & $\leq 2 / 38$ & $\mathrm{~S}$ & na & & $\leq 2 / 38$ \\
\hline Vancomycin & $\leq 2$ & $\mathrm{~S}$ & $\leq 2$ & $\mathrm{~S}$ & $\leq 2$ & $\mathrm{~S}$ & na \\
\hline
\end{tabular}

MSSA - methicillin-sensitive Staphylococcus aureus; MRSA - methicillin-resistant Staphylococcus aureus; S - susceptible; I - intermediate; R resistant; classification according to the interpretative breakpoints suggested by Clinical and Laboratory Standards Institute (CLSI) and European Committee on Antimicrobial Susceptibility Testing (EUCAST); na - not applicable.

MIC was defined as the lowest extract concentration that prevented the color change (from yellow dye to dark pink), caused by viable microorganisms, and exhibited the complete inhibition of bacterial growth.

Antioxidant activity. Hydroethanolic extracts were redissolved in ethanol/water $(80: 20, \mathrm{v} / \mathrm{v})$ to the final concentration of $20 \mathrm{mg} \mathrm{mL}^{-1}$ and further diluted to $0.156 \mathrm{mg} \mathrm{mL}^{-1}$ to be subjected to the following assays. The antioxidant activity was evaluated by DPPH radical-scavenging activity, reducing power, inhibition of $\beta$-carotene bleaching in the presence of linoleic acid radicals and inhibition of lipid peroxidation using TBARS in brain homogenates. ${ }^{21}$ The extract concentrations providing $50 \%$ of antioxidant activity or 0.5 of absorbance $\left(\mathrm{EC}_{50}\right)$ were calculated from the graphs of antioxidant activity percentages (DPPH, $\beta$-carotene bleaching and TBARS assays) or absorbance at $690 \mathrm{~nm}$ (reducing power assay) against extract concentrations. Trolox was used as a positive control.

Anti-inflammatory activity. The method previously described by Correa et $a l^{22}$ was performed in a concentration range 400-125 $\mu \mathrm{g} \mathrm{mL} \mathrm{mL}^{-1}$. Dexamethasone $(50 \mu \mathrm{M})$ was used as a positive control. The mouse macrophage-like cell line RAW 264.7 stimulated with LPS was used in the assay. Nitric oxide (NO) production was studied with a Griess Reagent System kit. Results were expressed as $\mathrm{EC}_{50}$ values $\left(\mu \mathrm{g} \mathrm{mL}^{-1}\right)$ equal to the sample concentration providing a $50 \%$ inhibition of $\mathrm{NO}$ production.

Cytotoxicity. Dry extracts (stock concentration $8 \mathrm{mg} \mathrm{mL}{ }^{-1}$, re-dissolved in water) were further diluted to different concentrations to be subjected to in vitro antitumor activity and hepatotoxicity evaluation at final well concentrations (400-1.5 $\mu \mathrm{g} \mathrm{mL} \mathrm{m}^{-1}$ ). The cytotoxicity was determined using four human tumour cell lines, HeLa (cervical carcinoma), HepG2 (hepatocellular carcinoma), MCF-7 (breast adenocarcinoma) and NCI-H460 (non-small cell lung cancer), following a procedure already described by the authors. ${ }^{17}$ The cell growth inhibition was measured using sulforhodamine B assay, where the amount of pigmented cells is directly proportional to the total protein mass and therefore to the number of bounded cells.
For hepatotoxicity evaluation, a freshly harvested porcine liver, obtained from a local slaughter house, was used in order to obtain the cell culture, designated as PLP2. The growth inhibition was evaluated using the SRB assay, as previously described. ${ }^{23}$ The results were expressed in $\mathrm{GI}_{50}$ values; sample concentration that inhibited $50 \%$ of the net cell growth. Ellipticine was used as a positive control.

\subsection{Statistical analysis}

Three repetitions (or two repetitions in case of antimicrobial assay) of the samples were used and triplicates for each concentration reading were carried out in all the assays. Results are expressed as mean values and standard deviations (SD). The results were analyzed using one-way analysis of variance (ANOVA) followed by Tukey's HSD test with $p=0.05$. When necessary, a Student's $t$-test was used to determine the significant difference among two different samples, with $p=0.05$. Both statistical treatments were carried out using the SPSS v. 23.0 program.

\section{Results and discussion}

\subsection{Phenolic compounds' profile}

Tables 4 and 5 present chromatographic data and tentative determination of phenolic compounds in the hydroethanolic extracts of leaves, stems, and roots of Solanum stramoniifolium Jacq. In leaves, 6 phenolic acid derivatives and 14 flavonoids (flavonol glycoside derivatives) were confirmed. Compounds 2 and 6 were positively identified as protocatechuic acid and 5-O-caffeoylquinic acid (chlorogenic acid) after comparing the obtained LC-MS data with those of commercial standards. Compound $\mathbf{5}$ was tentatively assigned as the corresponding cis isomer of 5-O-caffeoylquinic acid based on its fragmentation pattern and lower levels compared with peak 6. Furthermore, cis hydroxycinnamoyl derivatives would be expected to elute before the corresponding trans ones, as observed after UV irradiation (366 nm, $24 \mathrm{~h}$ ) of hydroxycinnamic acids in our 
Table 4 Retention time $\left(R_{\mathrm{t}}\right)$, wavelengths of maximum absorption in the visible region $\left(\lambda_{\max }\right)$, mass spectral data, and tentative identification of phenolic compounds in the hydroethanolic extract of Solanum stramoniifolium leaves

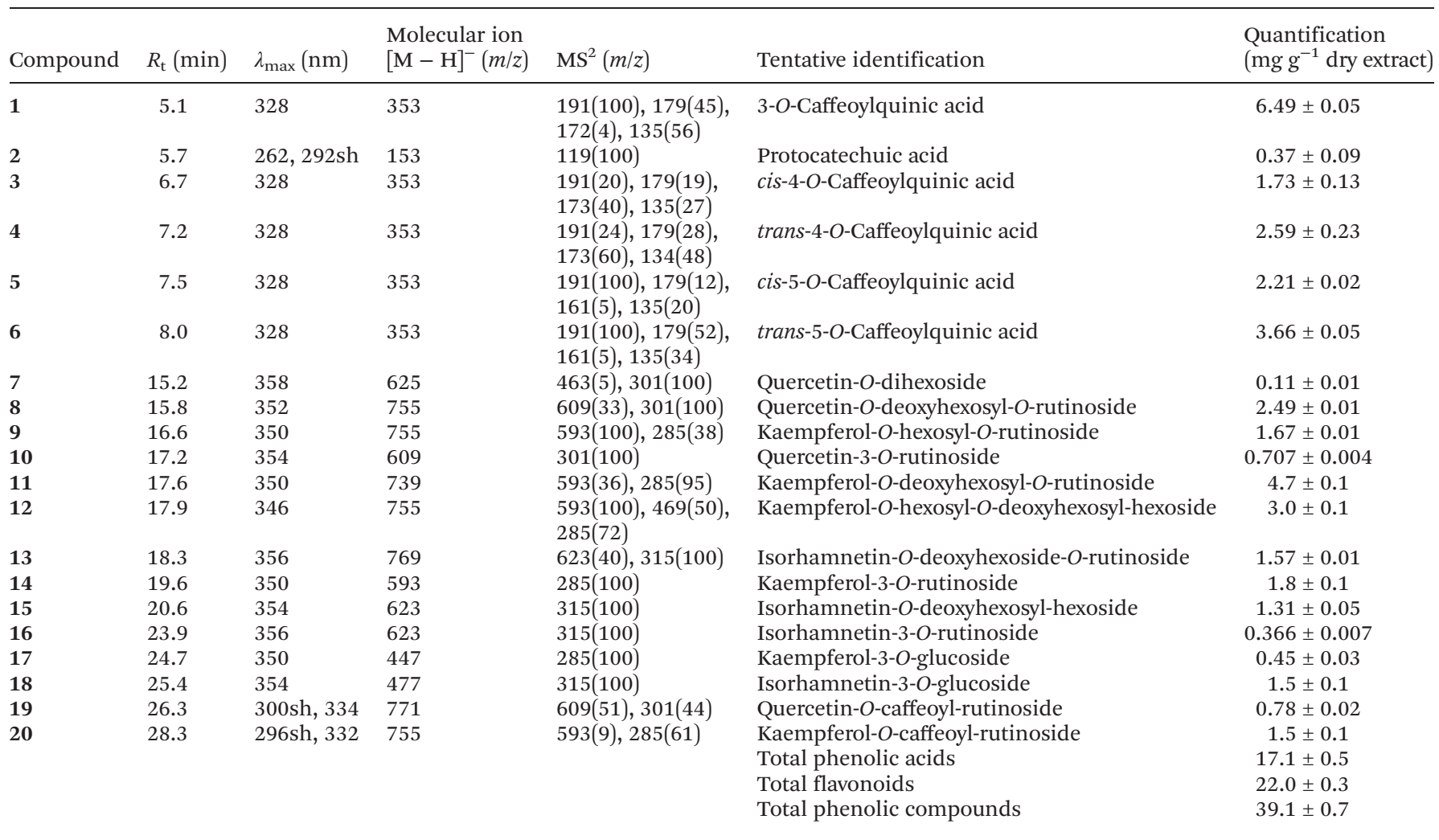

Table 5 Retention time $\left(R_{\mathrm{t}}\right)$, wavelengths of maximum absorption in the visible region $\left(\lambda_{\text {max }}\right)$, mass spectral data, and tentative identification of phenolic compounds in the hydroethanolic extract of Solanum stramoniifolium roots and stems

\begin{tabular}{|c|c|c|c|c|c|c|c|c|}
\hline \multirow[b]{2}{*}{ Compound } & \multirow[b]{2}{*}{$R_{\mathrm{t}}(\min )$} & \multirow[b]{2}{*}{$\lambda_{\max }(\mathrm{nm})$} & \multirow{2}{*}{$\begin{array}{l}\text { Molecular ion } \\
{[\mathbf{M}-\mathbf{H}]^{-}(m / z)}\end{array}$} & \multirow[b]{2}{*}{$\operatorname{MS}^{2}(m / z)$} & \multirow[b]{2}{*}{ Tentative identification } & \multicolumn{2}{|c|}{$\begin{array}{l}\text { Quantification } \\
\text { (mg g }{ }^{-1} \text { dry extract) }\end{array}$} & \multirow{2}{*}{$\begin{array}{l}\text { Student's } \\
t \text {-test }\end{array}$} \\
\hline & & & & & & Roots & Stems & \\
\hline 5 & 7.3 & 328 & 353 & $\begin{array}{l}\text { 191(100), 179(12), } \\
161(5), 135(20)\end{array}$ & cis-5-O-Caffeoylquinic acid & $2.62 \pm 0.22$ & $1.26 \pm 0.01$ & $<0.001$ \\
\hline 6 & 7.9 & 328 & 353 & $\begin{array}{l}\text { 191(100), 179(52), } \\
161(5), 135(34)\end{array}$ & trans-5-O-Caffeoylquinic acid & $5.03 \pm 0.14$ & $3.42 \pm 0.02$ & $<0.001$ \\
\hline 21 & 17.4 & $\begin{array}{l}236,296 \\
320 \text { sh }\end{array}$ & 472 & $350(40), 308(31)$ & $\begin{array}{l}\text { Bis(dihydrocaffeoyl) } \\
\text { spermidine isomer } 1\end{array}$ & $1.86 \pm 0.16$ & $0.43 \pm 0.01$ & $<0.001$ \\
\hline 22 & 20.3 & $\begin{array}{l}226,294, \\
322 \mathrm{sh}\end{array}$ & 799 & $\begin{array}{l}\text { 637(100), 515(6), } \\
472(10), 350(3), \\
308(3)\end{array}$ & $\begin{array}{l}\text { Tris(dihydrocaffeoyl) } \\
\text { spermidine hexoside }\end{array}$ & $0.63 \pm 0.10$ & $1.17 \pm 0.01$ & $<0.001$ \\
\hline 23 & 24.3 & 284 & 637 & $\begin{array}{l}515(23), 472(47) \\
350(15), 308(8)\end{array}$ & $\begin{array}{l}\text { Tris(dihydrocaffeoyl) } \\
\text { spermidine }\end{array}$ & $9.51 \pm 0.08$ & $1.06 \pm 0.02$ & $<0.001$ \\
\hline 24 & 29.4 & $\begin{array}{l}226,284 \\
316 \mathrm{sh}\end{array}$ & 472 & $350(32), 308(38)$ & $\begin{array}{l}\text { Bis(dihydrocaffeoyl) } \\
\text { spermidine isomer } 2\end{array}$ & $0.78 \pm 0.02$ & $0.46 \pm 0.05$ & $<0.001$ \\
\hline \multirow[t]{2}{*}{25} & 31.1 & $\begin{array}{l}226,292 \\
320 \mathrm{sh}\end{array}$ & 472 & $350(30), 308(48)$ & $\begin{array}{l}\text { Bis(dihydrocaffeoyl) } \\
\text { spermidine isomer } 3\end{array}$ & $0.55 \pm 0.09$ & $1.08 \pm 0.05$ & $<0.001$ \\
\hline & & & & & $\begin{array}{l}\text { Total phenolic compounds } \\
\text { and derivatives }\end{array}$ & $20.98 \pm 0.81$ & $8.89 \pm 0.01$ & $<0.001$ \\
\hline
\end{tabular}

laboratory. $^{24}$ cis and trans isomers of 4 -O-caffeoylquinic acid (compounds 3 and 4 ) and trans 3-O-caffeoylquinic acid (compound 1) were distinguished and identified by typical fragmentation patterns as described by Clifford et al. ${ }^{25,26}$ To the best of our knowledge these compounds were described in Solanum stramoniifolium Jacq. for the first time.

The flavonol derivatives detected in the leaf extract were mainly glycosides of quercetin $\left(\lambda_{\max }\right.$ around $354 \mathrm{~nm}$; $\mathrm{MS}^{2}$ frag- 
ment $m / z$ 301), isorhamnetin ( $\lambda_{\max }$ around $356 \mathrm{~nm}$; $\mathrm{MS}^{2}$ fragment $m / z$ 317), and kaempferol ( $\lambda_{\max }$ around $348 \mathrm{~nm}, \mathrm{MS}^{2}$ fragment $m / z 285$ ).

Quercetin-3-O-rutinoside (rutin; compound 10), kaempferol-3-O-rutinoside (nicotiflorin; compound 14), isorhamnetin-3-O-rutinoside (narcissin; compound 16), kaempferol-3-Oglucoside (astragalin; compound 17) and isorhamnetin-3-Oglucoside (compound 18) were positively identified upon comparison of their retention times, UV-Vis characteristics and mass spectra with available commercial standards.

Compound 7 presented a pseudomolecular ion $[\mathrm{M}-\mathrm{H}]^{-}$at $m / z 625$, releasing a $\mathrm{MS}^{2}$ fragment at $m / z 301$ ([M $-\mathrm{H}-162-$ $162]^{-}$, loss of two hexosyl moieties), which led to its tentative identification as quercetin-O-dihexoside. Compounds 8, 11, and $\mathbf{1 3}$ provided the same fragmentation losses of deoxyhexose $(146 \mathrm{u})$ and deoxyhexosyl-hexose (308 u), indicating the location of each residue on different positions of the aglycons of quercetin, kaempferol, and isorhamnetin $\left([\mathrm{M}-\mathrm{H}]^{-}\right.$at $m / z 755$, 739, and 769, respectively). Similarly, $\mathrm{MS}^{2}$ fragments of peaks 9 and 12 revealed the alternative loss of hexosyl $(\mathrm{m} / \mathrm{z}$ at $593 ;-162$ $\mathrm{u})$ and deoxyhexosyl-hexose $(\mathrm{m} / \mathrm{z}$ at $285 ;-308 \mathrm{u})$ residues. The positive identification of present rutinosides, including quercetin-3-O-rutinoside, in the samples may suggest a rutinoside identity for the deoxyhexosyl-hexose residues in peaks 8, 9, 11 and 13. However, in the case of peak 12, the information about the identity of the sugar moieties and location onto the aglycon could not be confirmed, therefore the compound was tentatively identified as kaempferol-O-hexosyl-O-deoxyhexosyl-hexoside. Compound $15\left([\mathrm{M}-\mathrm{H}]^{-}\right.$at $\left.m / z 623\right)$ presented the same pseudomolecular ion as compound 16, but showed an earlier retention time. The observation of just a single $\mathrm{MS}^{2}$ fragment $(\mathrm{m} / \mathrm{z}$ at 315 ; $-308 \mathrm{u}$ ), could indicate that the two sugar units were linked together and the compound was tentatively assigned as isorhamnetin-O-deoxyhexosyl-hexoside.

Compounds $19\left([\mathrm{M}-\mathrm{H}]^{-}\right.$at $\left.m / z 771\right)$ and $20\left([\mathrm{M}-\mathrm{H}]^{-}\right.$at $\mathrm{m} / \mathrm{z} 755)$ could correspond to compounds including an acylation with a phenolic acid. The observation in their fragmentation of a product ion at $m / z 609$ and 593, respectively, from the losses of caffeoyl residue (162 u), could also be coherent with that identity, as well as the late elution, since the presence of the hydroxycinnamoyl residue implies a decrease in polarity. Therefore, these molecules were tentatively assigned to quercetin-O-caffeoyl-rutinoside and kaempferol-O-caffeoyl-rutinoside.

The root and stem extracts gave a similar phenolic profile, obtaining different quantities of seven identified compounds. Compounds 5 and 6 were identified as 5-O-caffeoylquinic isomers cis- and trans- as described above. The root extract gave higher amounts of these substances than the stem extract. Compounds 21, 24, and $25\left([\mathrm{M}-\mathrm{H}]^{-}\right.$at $\left.m / z 472\right)$ were thought to represent polyamine derivatives, namely three isomers of $N, N^{\prime}$-bis(dihydrocaffeoyl)spermidine as described in the literature by Parr et $a .^{27}$ Similarly, and taking into account the findings reported by Gancel et al. ${ }^{28}$ compound 23 ([M $-\mathrm{H}]^{-}$at $m / z$ 637) lead to $N, N^{\prime}, N^{\prime \prime}$-tris(dihydrocaffeoyl)spermidine and its hexoside, compound 22; $[\mathrm{M}-\mathrm{H}]^{-}$at $\mathrm{m} / \mathrm{z} 799$, which gives a $\mathrm{MS}^{2}$ fragment at $m / z 637[\mathrm{M}-\mathrm{H}-162]^{-}$.
Nevertheless, a complete identification of the position of dihydrocaffeoyl groups on the spermidine skeleton was not possible. Compound $\mathbf{2 3}$ was the most abundant compound present in both parts of this species.

Flavonoids were the most abundant group of phenolic compounds identified in the present study. Nevertheless, polyamine derivatives (spermidines) were dominant in the root and stem extracts. To date, no record exists on spermidine derivatives in $S$. stramoniifolium, however, their presence was frequently described in other representatives of Solanum genus, such as potato (S. tuberosum) or naranjilla fruit (S. quitoense). ${ }^{28,29}$

\subsection{Biological activity}

The increasing number of bacterial strains resistant to severe available antibiotics remains a huge problem and is a driving force for the search of new compounds with antimicrobial activity. ${ }^{30}$ Furthermore, the food industry calls for natural antimicrobial additives that would be efficient and safe for human consumption at the same time. Various natural peptides, polysaccharides, terpenes, and phenolic compounds have been applied as food preservatives with no toxicity, such as thymol, carvacrol, chitosan, and nisin. ${ }^{31}$

The crude extracts of leaves, stems, and roots of S. stramoniifolium were tested for antimicrobial activity against selected clinical isolates representing both Gram-positive and Gram-negative bacteria: Acinetobacter baumannii, Klebsiella pneumoniae, Pseudomonas aeruginosa and Staphylococcus aureus, all known to exhibit multi-resistance to antibiotics and labeled as the ESKAPE pathogens (Enterococcus faecium, Staphylococcus aureus, Klebsiella pneumoniae, Acinetobacter baumannii, Pseudomonas aeruginosa, and Enterobacter species). ${ }^{32}$ It is established that the Gram-negative bacteria possess stronger resistance due to their protective outer membrane rich in lipopolysaccharides, ${ }^{33}$ which is missing in Gram-positive bacteria.

In Table 6, the results obtained from a broth microdilution method with INT colorimetric evaluation are displayed. As can

Table 6 Antibacterial activity of Solanum stramoniifolium hydroethanolic extracts (MIC; $\mathrm{mg} \mathrm{mL}^{-1}$ )

\begin{tabular}{|c|c|c|c|}
\hline \multirow[b]{2}{*}{ Bacteria } & \multicolumn{3}{|c|}{$\mathrm{MIC}\left(\mathrm{mg} \mathrm{mL}^{-1}\right)$} \\
\hline & Leaf & Root & Stem \\
\hline \multicolumn{4}{|l|}{ Gram-positive strains } \\
\hline MRSA & 5 & 10 & 5 \\
\hline MSSA & 5 & 10 & 5 \\
\hline Enterococcus faecalis & 5 & 10 & 10 \\
\hline Listeria monocytogenes & 20 & 10 & 2.5 \\
\hline \multicolumn{4}{|l|}{ Gram-negative strains } \\
\hline Acinetobacter baumannii & 10 & 10 & $>20$ \\
\hline Escherichia coli & 5 & 10 & 20 \\
\hline Escherichia coli ESBL & 5 & 10 & 20 \\
\hline Klebsiella pneumoniae & 5 & 10 & 20 \\
\hline Klebsiella pneumoniae ESBL & 5 & 10 & 20 \\
\hline Pseudomonas aeruginosa & 10 & 20 & $>20$ \\
\hline
\end{tabular}

$\mathrm{ESBL}=$ spectrum extended producer of $\beta$-lactamases. $\mathrm{MIC}=$ minimal inhibition concentration. MRSA = methicillin-resistant Staphylococcus aureus. MSSA = methicillin-sensitive Staphylococcus aureus. 
be seen, all three extracts exhibited antimicrobial activity to all the assayed bacteria, and MICs ranged from 2.5 to 20 $\mathrm{mg} \mathrm{mL} \mathrm{m}^{-1}$. In two cases, the MIC was above the maximal tested concentration (stem extract against $A$. baumannii and $P$. aeruginosa). In general, the Gram-positive bacteria were more sensitive to the extracts than Gram-negative bacteria, as expected. However, the root extract presented non-selective inhibition providing the same MIC values for 9 of 10 bacterial strains $\left(10 \mathrm{mg} \mathrm{mL}^{-1}\right)$. On the other hand, the stem extract was significantly more active against Gram-positive bacteria. Listeria monocytogenes was the most susceptible organism providing the lowest MICs in stem extract $\left(2.5 \mathrm{mg} \mathrm{mL} \mathrm{mL}^{-1}\right)$. $P$. aeruginosa was the least inhibited organism in the assay. Overall, the leaf extract was the most effective inhibitor with MICs of $5 \mathrm{mg} \mathrm{mL} \mathrm{m}^{-1}$ obtained for 7 clinical isolates. Notably, the bacteria with special characteristics, such as methicillinresistant MRSA or $\beta$-lactamase producing $E$. coli and K. pneumoniae, did not present higher MICs than their more sensitive analogues. The water extract of seeds from S. stramoniifolium (Thailand) showed significant multispectral inhibition ( $S$. aureus, P. aeruginosa, Bacillus. subtilis, Bacillus licheniformis, Xanthomonas sp., Salmonella typhi), however inhibition of $E$. coli and $K$. pneumoniae were not observed in the disc diffusion test. ${ }^{12}$

From the phenolic compounds identified in the plant parts, nicotiflorin, rutin, and chlorogenic acid were previously related with antimicrobial activity in the Solanum genus ${ }^{34}$ and therefore can contribute to the inhibitory potential of this species.

The results of antioxidant, anti-inflammatory and cytotoxic activity are included in Table 7 , due to their possible relationship previously described in the literature. ${ }^{35,36}$ Polyphenol extracts have been used in the food industry as they often exert multiple biological activities in protection against spoilage and oxidation via synergism of the compounds they contain. ${ }^{31}$

The antioxidant activity was evaluated using four in vitro assays covering various mechanisms, such as hydrogen atom transfer (HAT) and single electron transfer (SET), to fully unfold the antioxidant capacity of the studied samples. ${ }^{37}$

As it can be observed in Table 7, all plant part extracts showed significant antioxidant potential in the four assays (DPPH; reducing power, $\beta$-carotene bleaching inhibition and TBARS). The root extract stands out when compared to the other plant parts. It was significantly more effective than trolox standard in all antioxidant assays, providing lower $\mathrm{EC}_{50}$ values in each of the tested assays. Regarding DPPH scavenging capacity assay, the plant parts were declining as follows: root > leaf $>$ stem with the corresponding $\mathrm{EC}_{50}$ values of $13 \pm 1 ; 50 \pm$ 2 and $74 \pm 4 \mu \mathrm{g} \mathrm{mL} \mathrm{m}^{-1}$, respectively. In reducing power assay, two extracts provided better results than the standard trolox $\left(\mathrm{EC}_{50}=41.7 \pm 0.3 \mu \mathrm{g} \mathrm{mL} \mathrm{m}^{-1}\right)$, namely root and leaf $\left(\mathrm{EC}_{50}\right.$ of $8.68 \pm 0.03$ and $23.7 \pm 0.1 \mu \mathrm{g} \mathrm{mL} \mathrm{m}^{-1}$, respectively). The order of activity in reducing power was: root $>$ leaf $>$ stem, as observed in DPPH assay as well. Moreover, the same two extracts proved to be better $\beta$-carotene bleaching inhibitors than trolox, as only the stem extract gave a higher $\mathrm{EC}_{50}$ value than this standard $\left(23.4 \pm 0.4\right.$ versus $\left.18 \pm 1 \mu \mathrm{g} \mathrm{mL}^{-1}\right)$. In the TBARS inhibition test, only the root extract exceeded trolox capacity, however the results were still quite promising (root $>$ leaf $>$ stem; $\mathrm{EC}_{50}$ values corresponding to $15 \pm 1 ; 33 \pm 1$ and $60 \pm$ $1 \mu \mathrm{g} \mathrm{mL} \mathrm{m}^{-1}$, respectively). Previously, Wetwitayaklung and Phaechamud $^{10}$ observed low scavenging activity for the methanol fruit extract of $S$. stramoniifolium in TEAC assay using the $\mathrm{ABTS}^{+}$radical $\left(\mathrm{IC}_{50}=1133.08 \mu \mathrm{g}\right.$ compared to $10.14 \mu \mathrm{g}$ for trolox) and correlated it to the low presence of total phenolic compounds (1.55 g gallic acid equivalents per $100 \mathrm{~g}$ extract).

Table 7 Biological activity of hydroethanolic extracts from different parts of Solanum stramoniifolium Jacq

\begin{tabular}{|c|c|c|c|c|}
\hline & Leaf & Root & Stem & Trolox \\
\hline TBARS inhibition & Leaf & Root & Stem & Dexamethasone \\
\hline & Leaf & Root & Stem & Ellipticine \\
\hline \multicolumn{5}{|c|}{ Cytotoxicity to tumor cell lines ( $\mathrm{GI}_{50}$ values, $\mu \mathrm{g} \mathrm{mL}^{-1}$ ) } \\
\hline HeLa (cervical carcinoma) & $97 \pm 4 \mathrm{~b}$ & $206 \pm 15 \mathrm{a}$ & $>400$ & $1.91 \pm 0.06 \mathrm{c}$ \\
\hline
\end{tabular}

Trolox, dexamethasone and ellipticine, respectively, were used as positive controls in the assays. All values are means \pm SD $(n=9)$ and in each row different letters represent significant differences $(p<0.05)$. 
Lipid peroxidation products (e.g. malondialdehyde), as well as free radicals, may damage important cell macromolecules, such as DNA, proteins, and lipids and contribute to the development of pathological processes, including aging, cancer, atherosclerosis, coronary heart disease or neurodegenerative problems. ${ }^{38}$ Despite the effectiveness of endogenous antioxidant systems, an exogenous source of antioxidants is necessary in the case of excessive presence of oxidative species. Therefore, prevention or limitation of oxidative stress might be achieved by dietary antioxidants, such as phenolic-rich plant extracts.

From the tested plant parts, only the root revealed activity in the NO production $\left(\mathrm{EC}_{50}=100 \pm 6 \mu \mathrm{g} \mathrm{mL}^{-1}\right)$ as stated in Table 7. Leaf and stem did not show any activity within the maximal concentration tested $\left(400 \mu \mathrm{g} \mathrm{mL}{ }^{-1}\right)$, which is surprising according to the traditional choice of leaves for external inflammation. It can be suggested that other than NO production-related mechanisms are involved and different assays shall be evaluated in future to study this activity.

More than $60 \%$ of agents used in cancer therapy are from natural sources, especially tropical plants. ${ }^{39}$ The Solanum genus is a good source for anticancer substances, such as solanine or solamargine. ${ }^{40,41}$ The antitumor potential was evaluated against four human tumor cell lines represented by MCF-7 (breast carcinoma), NCI-H460 (non-small cell lung cancer), HeLa (cervical carcinoma) and HepG2 (hepatocellular carcinoma), and porcine liver primary culture PLP2 was selected for cytotoxicity assessment against non-tumor cells. Observing the results presented in Table 7, it can be concluded that leaf and root are the most promising plant parts with antitumor compounds as they inhibited all tumor cell lines used in the study. The highest inhibition was found for HepG2, yielding the lowest $\mathrm{GI}_{50}\left(40 \pm 3 \mu \mathrm{g} \mathrm{mL}^{-1}\right.$ for root and $85 \pm 6$ $\mu \mathrm{g} \mathrm{mL} \mathrm{m}^{-1}$ for leaf extract). The stem extract was efficient only in MCF-7 cell line inhibition $\left(\mathrm{GI}_{50}=242 \pm 4 \mu \mathrm{g} \mathrm{mL}{ }^{-1}\right)$. The most sensitive cell line was MCF-7, which was inhibited by all three extracts in the following order root $>$ leaf $>$ stem. Interestingly, the root extract provided lower $\mathrm{GI}_{50}$ for HepG2, MCF-7 and NCI-H460 than leaf, but was less effective against HeLa cell line. Compared to ellipticine, the extracts revealed medium activity. Nevertheless, ellipticine has a very strong inhibiting power on all presented tumor cell lines, but also exhibits high hepatotoxicity to non-tumor PLP2 cell line. In our case, only root showed mild hepatotoxicity towards PLP2 $\left(\mathrm{GI}_{50}=252 \pm\right.$ $10 \mu \mathrm{g} \mathrm{mL}{ }^{-1}$ ), however it did not exceed active concentrations against the tumor cell lines $\left(40 \pm 3 \mu \mathrm{g} \mathrm{mL}{ }^{-1}\right.$ in HepG2; $52 \pm$ $5 \mu \mathrm{g} \mathrm{mL} \mathrm{m}^{-1}$ in MCF-7; $113 \pm 5 \mu \mathrm{g} \mathrm{mL}{ }^{-1}$ in NCI-H460; and $206 \pm$ $15 \mu \mathrm{g} \mathrm{mL} \mathrm{m}^{-1}$ in HeLa).

Consequently, although the leaf and root extracts of S. stramoniifolium could be useful in the development of new anticancer products, the leaf is the most promising part, since it did not present unspecific toxicity, as suggested by results obtained with the PLP2 assay.

Due to the possible synergetic effect of present compounds, the plant crude extracts can often be a more powerful antioxidant tool than individual substances. Moreover, the natural matrices in the form of crude extracts possess usually very low toxicity compared to individual chemicals and therefore are currently experiencing a renaissance in both the phytopharmacological and food industry. ${ }^{31}$

\section{Conclusions}

This study highlights the potential of different parts of Solanum stramoniifolium Jacq. as a rich source of biologically active compounds suitable for applications in the food industry, for example in the development of novel functional foods and nutraceutical formulations. Ethanol/water extracts from leaves, stems, and roots demonstrated to have a strong biological activity. The root extract gave the highest antioxidant potential exceeding trolox standard values. It also significantly inhibited the growth of MCF-7 and HepG2 tumor cell lines. The leaf extract showed the best results in the antimicrobial assay inhibiting all the clinical bacterial isolates. Furthermore, it did not possess any cytotoxicity, unlike the root extract, and therefore might be a better candidate for the food industry. The phenolic compounds in the extracts revealed the content of compounds known for their biological activities, such as caffeoylquinic acid derivatives, flavonoids and polyamines. The presence of these compounds could be correlated with the high biological activity shown by these extracts. Several compounds were determined for the first time in this plant.

\section{Conflict of interest}

No conflict of interest.

\section{Acknowledgements}

The authors thank the Foundation for Science and Technology (FCT, Portugal) and FEDER under Programme PT2020 for financial support to CIMO (UID/AGR/00690/2013) and L. Barros (SFRH/BPD/107855/2015), S. Heleno (SFRH/BPD/ 101413/2014) and R. C. Calhelha (SFRH/BPD/BPD/68344/2010) grants. To POCI-01-0145-FEDER-006984 (LA LSRE-LCM), funded by FEDER, through POCI-COMPETE2020 and FCT. This study was financially supported by Internal Grant Agency of Tomas Bata University in Zlin, project no. IGA/FT/2016/003.

\section{References}

1 M. Carocho and I. C. F. R. Ferreira, Food Chem. Toxicol., 2013, 51, 15-25.

2 O. Paredes-Lopez, M. L. Cervantes-Ceja, M. Vigna-Perez and T. Hernandez-Perez, Plant Foods Hum. Nutr., 2010, 65, 299308.

3 D. A. Herms and W. J. Mattson, Q. Rev. Biol., 1992, 67, 283335. 
4 M. D. Whalen, D. E. Costich and C. B. Heiser, Gentes Herbarum, 1981, 12, 41-129.

5 H. B. Das, K. Majumdar, B. K. Datta and D. Ray, Nat. Prod. Radiance, 2009, 8, 172-180.

6 R. A. DeFilipps, S. L. Maina and J. Crepin, Medicinal Plants of the Guianas (Guyana, Surinam, French Guiana), Department of Botany, National Museum of Natural History, Smithsonian Institution, Washington, D. C., 2004, $491 \mathrm{p}$.

7 C. T. Pedrollo, V. F. Kinupp, G. Shepard Jr. and M. Heinrich, J. Ethnopharmacol., 2016, 186, 111-124.

8 Y. Estevez, D. Castillo, M. T. Pisango, J. Arevalo, R. Rojas, J. Alban, E. Deharo, G. Bourdy and M. Sauvain, J. Ethnopharmacol., 2007, 114, 254-259.

9 W. Samee, M. Engkalohakul, N. Nebbua, P. Direkrojanavuti, C. Sornchaithawatwong and N. Kamkaen, Thai Pharm. Health Sci. J., 2006, 1, 196-203.

10 P. Wetwitayaklung and T. Phaechamud, Res. J. Pharm., Biol. Chem. Sci., 2011, 2, 146-154.

11 A. Sakunpak and P. Panichayupakaranant, Food Chem., 2012, 130, 826-831.

12 R. Sarnthima and S. Khammuang, Int. J. Agric. Biol., 2012, 14, 111-115.

13 I. C. S. Aires, R. A. Lima and A. G. S. Braga, in $64^{\circ}$ Congresso Nacional de Botânica, Belo Horizonte, Brazil, 2013.

14 R. Pingal, Thesis, University of West Indies, 2008.

15 PAHO/WHO, 2013. http://www.paho.org/hq/index.php? option=com_content\&view=article\&id=9135\%3A2013-cancermortality-declining-some-countries-americas-new-pahowho-report\&catid=740\%3Apress-releases\&Itemid=1926<=en (accessed May 2016).

16 H. Chandoura, J. C. M. Barreira, L. Barros, C. SantosBuelga, I. C. F. R. Ferreira and L. Achour, Ind. Crops Prod., 2015, 65, 383-389.

17 L. Barros, E. Pereire, R. C. Calhelha, M. Duenas, A. M. Carvalho, C. Santos-Buelga and I. C. F. R. Ferreira, J. Funct. Foods, 2013, 5, 1732-1740.

18 CLSI, Performance Standards for Antimicrobial Susceptibility Testing, 18th informational supplement. CLSI document M100-S18, Clinical and Laboratory Standards Institute, Wayne, PA, USA, 2008.

19 EUCAST, European Society of Clinical Microbiology and Infectious Diseases, 2013. http://www.eucast.org/ ast_of_bacteria/previous_versions_of_documents/ (accessed March 2016).

20 V. Kuete, P. Y. Ango, G. W. Fotso, G. D. W. F. Kapche, J. P. Dzoyem, A. G. Wouking, B. T. Ngadjui and B. M. Abegaz, BMC Complementary Altern. Med., 2011, 11, 42-46.
21 J. Pinela, L. Barros, M. Dueñas, A. M. Carvalho, C. SantosBuelga and I. C. F. R. Ferreira, Food Chem., 2012, 135, 1028-1035.

22 R. C. G. Correa, A. Henrique Pereira de Souza, R. C. Calhelha, L. Barros, J. Glamoclija, M. Sokovic, R. M. Peralta, A. Bracht and I. C. F. R. Ferreira, Food Funct., 2015, 6, 2155-2164.

23 R. M. V. Abreu, I. C. F. R. Ferreira, R. C. Calhelha, R. T. Lima, M. Helena Vasconcelos, F. Adega, R. Chaves and M.-J. R. P. Queiroz, Eur. J. Med. Chem., 2011, 46, 5800-5806.

24 L. Barros, M. Dueñas, A. M. Carvalho, I. C. F. R. Ferreira and C. Santos-Buelga, Food Chem. Toxicol., 2012, 50, 15761582.

25 M. N. Clifford, K. L. Johnston, S. Knight and N. Kuhnert, J. Agric. Food Chem., 2003, 51, 2900-2911.

26 M. N. Clifford, J. Kirkpatrick, N. Kuhnert, H. Roozendaal and P. R. Salgado, Food Chem., 2008, 106, 379-385.

27 A. J. Parr, F. A. Mellon, I. J. Colquhoun and H. V. Davies, J. Agric. Food Chem., 2005, 53, 5461-5466.

28 A. L. Gancel, P. Alter, C. Dhuique Mayer, J. Ruales and F. Vaillant, J. Agric. Food Chem., 2008, 56, 11890-11899.

29 C. E. Narváez-Cuenca, J. P. Vincken and H. Gruppen, Food Chem., 2012, 130, 730-738.

30 G. Normanno, G. La Salandra, A. Dambrosio, N. C. Quaglia, M. Corrente, A. Parisi, G. Santagada, A. Firinu, E. Crisetti and G. V. Celano, Int. J. Food Microbiol., 2007, 115, 290-296.

31 M. Carocho, M. F. Barreiro, P. Morales and I. C. F. R. Ferreira, Compr. Rev. Food Sci. Food Saf., 2014, 13, 377-399.

32 J. N. Pendleton, S. P. Gorman and B. F. Gilmore, Expert Rev. Anti-Infect. Ther., 2013, 11, 297-308.

33 D. I. Andersson and D. Hughes, Nat. Rev. Microbiol., 2010, 8, 260-271.

34 A. Kröner, N. Marnet, D. Andrivon and F. Val, Plant Physiol. Biochem., 2012, 57, 23-31.

35 A. Winczura, D. Zdzalik and B. Tudek, Free Radical Res., 2012, 46, 442-459.

36 A. M. Pisoschi and A. Pop, Eur. J. Med. Chem., 2015, 97, 5574.

37 R. L. Prior, X. L. Wu and K. Schaich, J. Agric. Food Chem., 2005, 53, 4290-4302.

38 B. N. Ames, M. K. Shigenaga and T. M. Hagen, Proc. Natl. Acad. Sci. U. S. A., 1993, 90, 7915-7922.

39 E. Elisabetsky and G. C. de Souza, Farmacogn. da planta ao Medicam., 2004, 2, 87-99.

40 M. Amir and S. Kumar, J. Sci. Ind. Res., 2004, 63, 116-124.

41 K. W. Kuo, S. H. Hsu, Y. P. Li, W. L. Lin, L. F. Liu, L. C. Chang, C. C. Lin, C. N. Lin and H. M. Sheu, Biochem. Pharmacol., 2000, 60, 1865-1873. 